\title{
Autonomit ja arvoteoria
}

\section{Paula Rauhala}

Osa marxilaisista tai marxilaisesti inspiroituneista yhteiskuntatieteilijöistä on hylännyt Marxin kapitalismikritiikin taloustieteellisen ja kvantitatiivisen puolen, vaikka pitääkin kiinni luokkanäkökulmasta ja osasta Marxin kapitalismikritiikkiä. Tässä artikkelissa pohdin, miksi näin on käynyt ja millaisia poliittisia seurauksia tällä siirrolla on. Kirjoitus on jatkoa toisaalla julkaistulle artikkelilleni "Tietotyö ja arvo" (Rauhala 2013). Tuossa artikkelissa arvostelin Jussi Vähämäen ja Eetu Virenin sinänsä mainiota kirjaa Perinnöttömien perinne (Tutkijaliitto 20II) siitä, että he hylkäävät Marxin arvoteorian uuden talouden analyysivälineenä liian kevyin perustein. Käsitykseni mukaan Marxin kapitalismianalyysi palvelisi myös kirjan kirjoittajien päämääriä. Siksi esitän, että asiaa tulisi vielä arvioida uudelleen.

\section{Marxin arvoteoria}

Marx lähtee siitä, että jokaisen yhteiskunnan on tuotettava, jaettava tuotteet ja kulutettava. Taloudessa on Marxin mukaan aina viime kädessä kyse yhteiskunnallisen työn jakautumisesta. Tavarantuotannossa työn jakautuminen eri tuotannonaloille tapahtuu markkinoiden kautta. Jakautumista säätelevät tavaroiden hinnat. Hintoja puolestaan säätelee perimmäisenä lakina työaika. Yhteiskunnallinen työ on siis hintojen selitysperusta, johon nojaten voidaan esimerkiksi väittää, että tavaran hinta poikkeaa sen todellisesta arvosta. Marx selitti arvoteoriansa perusteita Ludwig Kugelmannille 11. heinäkuuta 1868:

Lapsikin tietää, että jokainen kansakunta kuolisi nälkään, jos se keskeyttäisi työnteon vaikkapa vain muutamaksi viikoksi, vuodesta puhumattakaan. Yhtä tunnettua on, että erilaisten tarpeiden paljoutta vastaavaa tuotteiden määrää varten tarvitaan moninainen ja paljoudeltaan tietty määrä yhteiskunnallista kokonaistyötä. On itsestään selvää, ettei tietty yhteiskunnallisen tuotannon muoto voi missään tapauksessa lakkauttaa tätä yhteiskunnallisen työn määräsuhtaisen jakautumisen välttämättömyyttä; muuttua voi vain sen ilmenemismuoto. (Marx \& Engels 1976b, 208; kursiivi alkuperäinen) 
Marx tutkii Pääomassa niitä yhteiskunnallisia muotoja, joissa yhteiskunnallisen kokonaistyön jakautuminen kapitalistisessa tuotantotavassa ilmenee. Nämä porvarillisen taloustieteen kategoriat, kuten työpalkka, maankorko ja voitto ovat Marxille $(1974,82)$ "historiallisesti määrätyn tuotantotavan, tavarantuotannon, tuotantosuhteita ilmaisevia, yhteiskunnallisesti päteviä ja siis objektiivisia ajatusmuotoja".

Vain työ tuottaa arvoa ja lisäarvoa. Nämä kuitenkin jakautuvat markkinoilla kilpailun lakien mukaisesti. "Välittömän riiston ja sen realisoinnin ehdot eivät ole identtiset” (Marx 1976a, 247). Eniten lisätyötä riistävä kapitalisti ei realisoi korkeimpia voittoja. Lisäksi tuotetun lisäarvon jakamiseen osallistuu myös sellaisia pääomia, jotka eivät välittömästi osallistu sen riistämiseen, kuten pankki- ja kauppapääoma.

Kapitalismi on tavarantuotantoa: toisistaan riippumattomat yksityiset tuottajat tarjoavat tuotteitaan tavaroina markkinoilla. Yhteiskunnallinen työnjako jäsentyy näin markkinoiden välityksellä ja tuottajat ovat toisistaan keskinäisriippuvaisia. (Ks. Marx 1974, 51.) Tuottajien kilpailu markkinoilla toteuttaa arvolain, joka säätää tavaroiden tuottamiseksi edellytetyn yhteiskunnallisesti välttämättömän työajan hintojen viime kätiseksi perustaksi. Marxin mukaan "tuotteiden tuottamiseen yhteiskunnallisesti välttämätön työaika toteutuu tuotteiden tilapäisissä ja alati horjuvissa vaihtosuhteissa vain väkivaltaisesti säännöstelevänä luonnonlakina" (Marx 1974, 81). Kilpailun paineessa tuottajat eivät nimittäin voi käyttää tavaroidensa valmistamiseen enempää kuin keskimäärin yhteiskunnallisesti välttämättömän työajan.

Koska työn tuottavuutta parantava teknologia vähentää tavaran tuottamisen edellyttämää työaikaa, ennen yleistymistään uudet teknologiset innovaatiot mahdollistavat yksittäisille tuottajille lisävoittoja (Marx 1974, 291). Nämä tuottajat siis realisoivat markkinoilla voittoina enemmän lisäarvoa kuin kilpailijansa. Edelleen, kilpailu pakottaa tuottajia pysyttelemään mukana teknologisessa kehityksessä. Kilpailun ajama teknologian jatkuva kehitys vähentää kuitenkin talouden kokonaisuuden tasolla elävän työn osuutta tuotannossa. "[T]yön yhteiskunnallisen tuotantovoiman kehittyessä on tarpeen jatkuvasti kasvava määrä kokonaispääomaa saman työvoimamäärän panemiseksi liikkeelle saman lisätyömäärän nielemiseksi” (Marx 1976a, 224-225). Koska työ on ainoa lisäarvon ja siten voittojen lähde, 
kapitalistisen tuotantotavan on voitettava tämä ristiriita jatkuvasti toistuvien kriisien välityksellä (Marx 1976a, 261).

Niinpä vuoden 2008 kaltaiset romahdukset eivät ole tulleet marxilaisille taloustieteilijöille yllätyksenä, toisin kuin parhaassa mahdollisessa maailmassa eläville valtavirran taloustieteilijöille. Toisin kuin näiden tasapainomallit, marxilainen taloustiede lähtee talousjärjestelmän ristiriidoista. Näistä perustavin on antagonismi työväenluokan ja omistavan luokan taloudellisten intressien välillä.

Yhtäältä työväenluokan ja toisaalta tuotantovälineiden yksityisomistuksen olemassaolo on koko tuotantotavan olemassaolon ehtona. Pääomasuhde edellyttää työvoiman tavaraluonnetta, siis välittömien tuottajien erottamista tuotantovälineistään (Marx 1974, 641). Välittömistä tuottajista, itsenäisistä maanviljelijöistä tehtiin Englannissa uuden ajan alkupuolella vapaita palkkatyöläisiä, kun näiden maaomaisuus pakkolunastettiin, ja prosessi jatkuu edelleen. Marxin ironisen kuvauksen mukaan työläiset ovat kahdessa mielessä vapaita. He ovat vapaita myymään työvoimaansa tavarana. He ovat siis työvoimatavaransa yksityisomistajia, eivätkä itse tavaroita kuten orjat. Toisaalta he ovat vapaita työvoimansa realisoinnin ehdoista, tuotantovälineistä. (Marx 1974, 160.)

\section{Arvoteorian kritiikki}

Marxin arvoteoriaa on kritisoitu alkaen Eugen Böhm von Bawerkin Zum Abschluss des Marxschen Systems -teoksesta. Se ilmestyi 1896, kaksi vuotta Pääoman kolmannen osan julkaisun jälkeen. Böhm von Bahwerk katsoi, että Pääoman ensimmäinen ja kolmas osa ovat keskenään ristiriidassa.

Ladislaus von Bortkiewicz tarttui marxilaisen taloustieteen vaikeimpaan pulmaan artikkelissaan "Wertrechnung und Preisrechnung im Marxschen System" (1906-1907). Kyse on työarvojen transformoinnista tuotantohinnoiksi. Pääoman ensimmäisessä osassa Marx esittää tavarantuotannon olemuksellisen lain, arvolain. Pääoman kolmannessa osassa hän esittää puolestaan tuotantohintamallin, joka pätee kapitalistisen kilpailun oloissa. Jos työvoima ja pääoma saavat liikkua vapaasti tuotannonalalta toiselle, kilpailu tuppaa tasoittamaan voittoasteet (Marx 1976a, 199). Niinpä markkinahinnat perustuvat kapitalismissa tuotantohintoihin, jotka ovat 
muuntuneita työarvoja. Näiden kahden systeemin, työarvojen ja tuotantohintojen, suhde synnyttää kuitenkin taloustieteellisiä ongelmia.

Viimeisimmän Marxin arvoteorian vaikutusvaltaisen kritiikin ovat esittäneet uusricardolaiset taloustieteilijät, ennen kaikkea Ian Steedman kirjassaan Marx After Sraffa (1977). Uusricardolaisten mukaan työarvo on tieteellisesti tarpeeton käsite.

Marxilaiset taloustieteilijät ovat kehittäneet viime vuosikymmeninä useita vastauksia näihin kritiikkeihin. ${ }^{1}$ Myös marxilaiset yhteiskuntatieteilijät ja filosofit, jotka eivät kykene vastaamaan arvosteluun taloustieteen menetelmillä, ovat joutuneet reagoimaan käytössään olevin keinoin. Niin kutsutut arvomuototeoreetikot ja jotkut autonomimarxistit ovat kiertäneet kritiikin muokkaamalla Marxin teoriaa tai hylkäämällä sen kvantitatiivisen puolen kokonaan. Osa autonomeista on hylännyt koko teorian.

Arvoteorian puolustajat ovat ennen kaikkea painottaneet Ricardon ja Marxin arvoteorioiden eroa. Päoman alaotsikkohan kuuluu: "Poliittisen taloustieteen kritiikkiä". Marx ei siis missään nimessä omaksunut Ricardon arvoteoriaa sellaisenaan, vaan arvostelee Ricardon teoriaa systemaattisesti, etenkin historiallis-kriittisen näkökulman puutteesta. Vaikka Ricardo analysoikin kapitalisen talouden kategorioita pitkälti oikein, hän ei käsittänyt niiden historiallista luonnetta.

Toisin kuin klassiset poliittiset taloustieteilijät, jotka näkivät kapitalismin taloudelliset muodot ikuisina ja luonnollisina, Marxin poliittisen taloustieteen kritiikin päämääränä on osoittaa paitsi se, kuinka nämä muodot ovat syntyneet, myös niissä toistaiseksi toteutumattomina mahdollisuuksina asustavat kehityspotentiaalit (Zelený 1980, 18). Niinpä Marx - vaikka suuntasi sanomansa työväenluokalle - arveli Pääoman vaikuttaneen myös siten, että "[v]allassa olevien luokkienkin mielessä alkaa sarastaa aavistus, ettei nykyinen yhteiskunta olekaan mikään kiinteä kide, vaan muutoskykyinen ja alati muutosprosessissa oleva elimistö" (Marx 1974, 18). Kapitalismin taloudellisten suhteiden ja näiden suhteiden ilmenemismuotojen, kuten jo mainittujen pääomavoiton, maankoron ja työpalkan syntyhistorian jäljittäminen avaa perspektiivin myös niiden ylittämiseen ja korvaamiseen entistä kehittyneemmillä yhteiskunnallisilla suhteilla.

Tulkitessaan arvon fysikalistisesti, siis yksinkertaisesti tavaran työsisällöksi, uusricardolaiset taloustieteilijät eivät tee eroa ihmistyön ja koneen tai eläimen työn välillä. Kun minkä tahansa tuotannontekijän voidaan katsoa 
tuottavan arvoa, riiston merkitys katoaa. On yhtä perusteltua puhua öljyn kuin työn riistosta. (Saad-Filho 2002, 24.) Marxin arvoteoriassa ihmistyö kuitenkin eroaa yhteiskunnallisuutensa vuoksi laadultaan fysikaalisesta työstä. Tätä seikkaa Marxin arvoteorian uudet tulkinnat ovat - hyvästä syystä - painottaneet.

\section{Perinnöttömien perinteen perinne}

Kuten mainittu, muutamat autonomiteoreetikot ovat Antonio Negriä seuraten "ratkaisseet" arvoteorian ongelmat esittämällä, että arvolaki on kumoutunut tietokapitalismissa. Näiden teoreetikoiden mukaan perinteisen teollisen tuotannon hegemonisen aseman murtuminen merkitsee myös arvolain jäämistä historiaan, sillä tietotalous toimii toisenlaisten taloudellisten periaatteiden varassa kuin Marxin 1800-luvulla analysoima talousjärjestelmä. Tietotyön tuotteet eroavat muista tavaroista, koska ne eivät ole luonteeltaan niukkoja eivätkä eksklusiivisia. Toisaalta myös itse tietotyö organisoidaan toiseen tapaan kuin teollisen kapitalismin aikakaudelle tyypillinen työ.

Toiset autonomimarxistit pitävät kiinni Marxin arvoteoriasta ja painottavat luokkataistelua arvon tuotannon edellytyksenä. Ihmistyö eroaa eläimen ja koneen työstä, sillä ihminen kykenee kieltäytymään työstä poliittisesti, siis luokkana. Niinpä arvon yhteiskunnallinen ja historiallisesti spesifi luonne liittyy juuri luokkataisteluun. Esimerkiksi Gerhard Hanloserin ja Karl Reitterin mukaan lisätyön määrän ja siten riistoasteen määrää kamppailu työpäivän pituudesta, ei mikään objektiivinen taloudellinen laki (Hanloser \& Reitter 2008, 55).

Vaikka luokkanäkökulma on Marxin teoriassa keskeinen, Hanloserin ja Reitterin argumentissa on nähdäkseni kuitenkin ongelma. Kuten Axel Kicillof ja Guido Starosta huomauttavat, Marxin analyysissa työpäivän ja lisätyön pituutta määrittävät myös tuotantoteknologia ja työn intensiteetti, eivät yksin työväenluokan kamppailut (Kicillof \& Starosta 2007, 21). Jos käytössä on vain alkeellista teknologiaa, pitkäkään työpäivä ei tuota merkittävää lisätuotetta. Kehittynyt teknologia voi puolestaan mahdollistaa korkean riistoasteen, vaikka työpäivä olisi suhteellisen lyhyt. Kicillof ja Starosta $(2007,22)$ moittivatkin arvon luokkataistelutulkintaa 
luokkataistelun ontologisoinnista; ikään kuin kyseessä olisi koko todellisuutta - myös luontoa - määrittävä voima.

Suomen merkittävimpien autonomimarxilaisten tutkijoiden Eetu Virenin ja Jussi Vähämäen kirjassa Perinnöttömien perinne (2011) esitetään nähdäkseni sekä luokkataistelun merkitystä painottavia argumentteja että väite, jonka mukaan arvontuotanto on tietotaloudessa romahtanut. He esittävät toisaalta, että "[k]apitalismissa tuottava työ määrittyy poliittisesti [...] ei siis ole olemassa tuottavaa työtä annettuna ja ikuisena kategoriana, vaan se on aina luokkataistelun määrittämää” (Viren \& Vähämäki 2011, 147). Niinpä "[1]uokkataistelu sanelee sen, onko tämä tai tuo tuottavaa" (sama). Toisaalta heidän mukaansa arvolaki ei enää päde nykykapitalismissa, sillä nykytaloudessa

yleisestä älyllisestä työstä tulee tuottavan työn hegemoninen muoto, se marginalisoi muut tuottavan työn hahmot eikä sen mittaamiseen riitä erottelu yksinkertaiseen ja kompleksiseen tai tuottavaan ja tuottamattomaan (Viren \& Vähämäki 2011, 145).

Tietotyössä työaika ja vapaa-aika ovat tyypillisesti sekoittuneet. Se tekee välttämättömän työajan ja lisätyöajan määrittämisestä mahdotonta. Tietotyö on olemukseltaan kommunikatiivista ja perustuu yhteistyöhön. Arvon tuottanutta työntekijää tai edes yritystä ei näin ollen voida määrittää. Tietotyön tuotteet ovat puolestaan "immateriaalisia” ja kopioitavissa lähes ilmaiseksi. Ne eivät ole luonteeltaan kilpailullisia ja eksklusiivisia.

Nämä tietotyön piirteet eivät kuitenkaan muodosta ylitsepääsemätöntä ongelmaa nykytalouden selittämiselle arvoteorian avulla. Tietotyön tuotteiden arvo kyllä määräytyy omalaatuisella tavalla, mutta niiden olemisen tapa ei haasta Marxin teorian peruslogiikkaa. (Ks. Starosta 2012; Rauhala 2013.)

\section{Marxilainen vai uusklassinen taloustiede?}

Marxismin hylkääminen talousteoriana näyttää johtaneen siihen, että autonomimarxistien ajatteluun on pujahtanut valtavirran talousortodoksian oletuksia, joista seuraavia johtopäätöksiä luokkataistelun merkitystä 
painottavat autonomit tuskin kuitenkaan ovat valmiita hyväksymään.

Ensinnäkin teesi, jonka mukaan tietotyön tuotteet eivät noudata arvolakia, näyttää hyväksyvän oletuksen, jonka mukaan tavaroiden arvomuoto johtuu niiden luonnollisesta niukkuudesta. "Kilpailun logiikan edellytyksenä on [...] sen kohteena olevien resurssien niukkuus", Viren ja Vähämäki $(2011,90)$ toteavat ja jatkavat, että "[t]ieto tai muut aineettomat hyödykkeet eivät kuitenkaan ole luonnostaan niukkoja”. Tästä he vetävät johtopäätöksen, että "koska tietäminen ja tieto eivät ole niukkoja resursseja, tiedon vaihtoarvon eli sen hinnan nostaminen on keinotekoista ja riippuu poliittisesta kyvystä rajoittaa tiedon leviämistä ja sen saatavuutta” (sama). Mutta tavaroiden arvomuoto ei ole koskaan johtunut näiden luonnollisesta niukkuudesta!

Toiseksi argumentti näyttää sisältävän oletuksen, että arvo on yksittäisen tavaran ominaisuus. Virenin ja Vähämäen mukaan "arvolain katoaminen tapahtuu, kun 'kompleksista työtä' (ja yhteistyötä) ei enää voida palauttaa 'yksinkertaiseksi työksi' ja sen yksiköiksi sillä tavoin, että $n$ määrä yksinkertaista työtä muodostaa tavaran arvon A" (Viren \& Vähämäki 2011, 144). Väitteessä ei oteta huomioon sitä, että Marxin arvoteoriassa tavarat saavat arvonsa osana kokonaistuotteesta.

Käsittelin näiden argumenttien ongelmia Kulttuurivihkojen 2-3/2013 artikkelissani. Tässä otan esille kolmannen autonomien argumentaatiossa esiintyvän oletuksen. Autonomit nimittäin esittävät, että nykyään hegemonisen tietotyön tapauksessa tuotantovälineet ovat työväenluokan hallussa.

Viren ja Vähämäki väittävät, että " [t]eollisen kapitalismin aikana koneet olivat kapitalistin omaisuutta" ja että

toisin kuin koneet, joihin kapitalisti investoi ja jotka hän antoi työläisen käyttöön, urbaani perintö ja immateriaalinen elävä työ eivät kuitenkaan ole käyttäjistään erillisiä laitteita vaan heistä erottamattomia tai 'upotettuja' käyttäjiensä ruumiiseen sekä jokapäiväisen elämän käytäntöihin. (Viren \& Vähämäki 2011, 49.)

Sitaatissa esitetään, että tuotantovälineet on jo joka tapauksessa liitetty tietotyöläisten ruumiiseen ja tietoisuuten, sen sijaan, että heidän tietoisuutensa ja ruumiinsa liitettäisiin tuotantoprosessissa koneisiin (ks. myös Virno 
2007, 5). Kuten Lauri Lahikainen (2012) esittää, tämä argumentti on yhtenevä uusliberaalin 'inhimillisen pääoman' teorian kanssa siinä mielessä, että

siinä nähdään tuotantovälineiden jo olevan "multitudoksi" muuttuneen työväenluokan hallussa. Tämä kumoaa erottelun pääomanomistajiin ja työläisiin aivan kuten inhimillinen pääomakin. Kun kaikilla on pääsy tuotantovälineisiin - kieleen, avoimeen lähdekoodiin, kommunikaatioon ja niin edelleen - ei pääoma enää riistä työtä pakottamalla työläisiä riistosuhteeseen. (Lahikainen 2012, 59.)

Todellisuudessa kuitenkin, kuten Lahikainen painottaa,"työläis-kapitalistin” ja kapitalistin erona säilyy edelleen se, että jälkimmäinen voi laittaa pääomansa tuotantoprosessiin uhraamatta omaa elämänaikaansa, terveyttään ja onneaan, kun taas edellinen myydessään "pääomaansa" myy oman sielunsa ja ruumiinsa toisen käyttöön. (Lahikainen 2012, 97.)

Kuten Lahikainen huomauttaa, Marx arvosteli Adam Smithiä työvoiman ja pääoman sekoittamisesta. Marxin mukaan työläinen ei ole kapitalisti, vaikka hän myykin markkinoilla erästä tavaraa, omaa nahkaansa.

Viren ja Vähämäki ottavatkin toisaalta etäisyyttä "inhimillisen pääoman" teoretisointiin:

[t]iedämme, että tuotantovälineet - ihmisruumiin aivot ja aistimiskyvyt, kyvyt tietää ja tuntea - eivät yksittäisen tuottajan tai tuottajien omaisuutena ja keskinäisinä käytäntöinä, heidän hallussaan olevina, ole pääomaa. Aivoista ja ajattelukyvystä voi tulla pääomaa ainoastaan sillä ehdolla, että ne ovat samalla työläisen riistämisen ja hallitsemisen välineitä. (Viren \& Vähämäki 2011, 90.)

Aivojen ja aistimiskykyjen kutsuminen tuotantovälineiksi on nähdäkseni ongelmallista, sillä nämä ovat työvoiman ominaisuuksia, ja työntekijä, filosofikin, tarvitsee tuotantoon aina muutakin kuin aivonsa. Jos tuotantovälineet ovat jo työväenluokan hallussa, riisto paikannetaan markkinoille. Viren ja Vähämäki katsovatkin, että suhteellisen lisäarvon tuotantoon perustuvan 
riiston sijaan kapitalistien voittojen lähteenä ovat tänä päivänä

työn ja tuotannon joustavuus, tiedon keskeinen ja välitön asema tuotannossa, yhteiskunnalliset ja dynaamiset (skaala)taloudet (joissa tärkeässä asemassa ovat oppiminen ja verkostot), tuotannon laajentaminen uusintamisen ja kulutuksen piiriin, aineettoman tuotannon keskeinen asema ja koko elämän alistaminen pääomalle. (Viren \& Vähämäki 2011, 193.)

Kapitalistin ei siis tarvitse enää organisoida työväenluokkaa erityiseen työaikaan ja työpaikkaan lisäarvoa tuottamaan. Riittää, että postmodernin työväenluokan, "multitudon" tai "väen" itsenäisesti, ilman pääoman käskyvaltaa tuottama arvo kaapataan jälkikäteen yksityisomaisuudeksi. Riisto ei perustu enää ensi sijassa lisätyöajan anastamiseen, vaan toimii pikemminkin alkuperäisen kasautumisen tai (maan)koron periaatteella: kommunistisesti tuotettu kaapataan juridisin keinoin yksityisomaisuudeksi ja siitä ryhdytään perimään käyttökorvauksia. (Ks. Viren \& Vähämäki 2011, 169.)

Tällainen näkökulma jättää tuotantoprosessin tarkastelun ulkopuolelle. Näin kamppailu riistoa vastaan pelkistyy kysymykseksi työn tuotteen jakamisesta (Metzger 2011, 5; Hermann 2009, 286). Tämä on sääli, sillä marxilainen talousteoria, verrattuna uusklassiseen, keynesiläiseen ja vaikka uusricardolaiseen teoriaan, auttaa ymmärtämään markkinoiden lisäksi tuotantoprosessia. Kapitalistisesti kehitetty teknologia ja työn organisoinnin muodot eivät ole neutraaleja, sillä ne perustuvat ennen muuta voiton tuottamisen imperatiiville.

\section{Työajan lyhentäminen}

Marxille $(1974,224)$ pääoma on esineellistynyttä, maksamatonta työaikaa. Marx siteeraa tehtaantarkastajaa, joka väittää, että "ajan atomit ovat voiton alkeita". Tämä kiteytys perustuu tehtaantarkastajan havaintoihin siitä, että työnantaja pihistää työläiseltä minuutin tai pari aina kuin mahdollista, siis varastaa työläisen elämänaikaa esimerkiksi tinkimällä tämän pissa- ja ruokatauoista. Marxin arvoteorian ytimessä on siis työaika, jota mitataan kellolla, ja joka ilmenee tavarantuotannossa rahan muodossa. 
Kapitalismi on kehittänyt tuotantovoimia, tuotantoteknologiaa ja työn organisoinnin muotoja niin pitkälle, että sosialistisin periaattein järjestetty tuotanto mahdollistaisi tänä päivänä työajan radikaalin lyhentämisen. Kapitalismin olosuhteissa työajan lyhentäminen ei marxistien mukaan kuitenkaan tule kysymykseen, sillä voitot ovat viime kädessä maksamatonta lisätyöaikaa. Kapitalistien kiihko pidentää niin perinteisten työläisten kuin tietotyöläistenkin työaikaa seuraa objektiivisesta taloudellisesta välttämättömyydestä.

Virenin ja Vähämäen mukaan arvontuotanto on levinnyt työajasta myös vapaaseen aikaan ja kulutukseen: "vieraan työajan varastamisen viheliäiselle perustalle rakentunut kapitalismi siirtyy koko elämän varastamiseen" (Viren \& Vähämäki 2011, 144). Tämä johtuu siitä, että “[f]inanssimarkkinat eivät riistä vain työtä ja työläisiä, ne riistävät koko elämää” (Viren \& Vähämäki 2011, 193). Siksi “[o]n luotava keinoja jotka vapauttavat myös työn ulkopuolisen yhteiskunnallisen elämän lisäarvon tuottamisen pakosta” (sama).

Empiria kuitenkin sotii argumenttia vastaan. Kuten työelämän tutkija Chirstoph Hermann esittää, työaika pidentyy jälleen myös länsimaissa. OECD, IMF ja Euroopan komissio kiittävät tätä kehitystä työn hyödyntämisasteen parantumisesta (rate of labour utilization). Hermannin mukaan tämä muistuttaa marxilaista riistoasteen käsitettä. (Hermann 2012).

Tieteen tai taiteen parissa askartelun, lasten hoitamisen ja opiskelun parissa vietettyä aikaa sen sijaan ei pyritä pidentämään. Jos näissä todella tuotettaisiin arvoa ja lisäarvoa, niin silloinhan omistava luokka toimisi irrationaalisesti, sillä työajasta - toisin kuin vapaasta ajasta - joutuu useimmiten maksamaan palkkaa. Marxin teoria selittää, miksi kapitalisteilla on työaikafiksaatio ja miksi yhteiskunnan tahti kiihtyy koko ajan. Jos taas ajatellaan, että arvoa luodaan vapaalla ajalla, niin silloin voisi kuvitella, että nimenomaan leppoistaminen edesauttaisi arvon tuotantoa.

Marxin kapitalismianalyysi ei sovi yhteen uusklassisen taloustieteen eikä keynesiläisyyden kanssa (vaikka jälkimmäinen on marxisteille epäilemättä tärkeä poliittinen liittolainen). Marxismia ei kannata hylätä talousteoriana, sillä se osoittaa, että kapitalismin ylittäminen on paitsi poliittinen, myös taloudellinen välttämättömyys. Marxin arvoteorian ja talousteorian käyttökelpoisuutta tulisi tarkastella tältä pohjalta. Vaikka teoriaan liittyy omat ongelmansa, ne ongelmat eivät kuitenkaan johdu siitä, etteikö se soveltuisi myös uuden talouden analyysin välineeksi. 


\section{Viitteet}

I) Andrew Kliman (2007) avaa Marxin teorian kritiikkejä ja marxilaisten taloustieteilijöiden vastauksia ei-taloustieteilijöille.

\section{Lähteet}

Hanloser, Gerhard ja Reitter, Karl. 2008. Der bewegte Marx - Eine einführende Kritik des Zirkulationsmarxismus. Münster: UNRAST-Verlag.

Hermann, Christoph. 2012. Neoliberalism and the End Of Shorter Work Hours", Socialist Project - E-Bulletin No. 590, January 25. URL: <http://www. socialistproject.ca/bullet/590.php>. Katsottu 9.12. 2014.

Hermann, Christoph. 2009. Value and Knowledge: Insights from Marxist Value Theory for the Transformation of Work in the Digital Economy. Rethinking Marxism, 21:2, 275-289.

Kicillof, Axel ja Starosta, Guido. 2007. Value-form and Class Struggle. A critique of the autonomist theory of value. Capital \& Class 31:2, 13-40.

Kliman, Andrew. 2007. Reclaiming Marx's 'Capital'. A Refutation of the Myth of Inconsistency. Plymouth: Lexington Books.

Lahikainen, Lauri 2012. Inhimillinen pääoma ja riisto. Pro-gradu -tutkielma, Tampereen yliopisto. http://tampub.uta.fi/bitstream/handle/10024/83961/ gradu06209.pdf?sequence=1 [Luettu 9.12. 2014]

Marx, Karl. 1976a [1894]. Pääoma. Kansantaloustieteen arvostelua. 3 osa. Suom. Antero Tiusanen. Suomennoksen tarkistanut Tuure Lehén. Moskova: Edistys.

Marx, Karl ja Engels Friedrich. 1976b. Kirjeitä. Suom. Timo Koste ja Vesa Oittinen. Moskova: Edistys.

Marx, Karl 1974 [1867], Pääoma. Kansantaloustieteen arvostelua. 1 osa, Edistys, Moskova, . Suom.O. V. Louhivuori, käännöksen tarkistaneet Tuure Lehén ja Mauri Ryömä. 
Metzger, Philipp. 2011. Werttheorie des Postoperaismus. Eine Kritik an der postoperaistischen Interpretation des Marx'schen Wertgesetzes. Phase 2. Zeitschrift gegen die Realität, 42. http://phase-zwei.org/hefte/artikel/ werttheorie-des-postoperaismus-63/ [Luettu 9.12. 2014]

Rauhala, Paula. 2013. Tietotyö ja arvo. Kulttuurivihkot, 2-3, 59-64.

Saad-Filho, Alfredo. 2002. The Value of Marx. London \& New York: Routledge.

Starosta, Guido. 2011. Cognitive Commodities and the Value-Form. Science \& Society, 76:3, 365-392.

Virno, Paulo. 2007. General Intellect. Historical Materialism, 15, 3-8.

Viren, Eetu ja Vähämäki, Jussi. 2011, Perinnöttömien perinne. Helsinki: Tutkijaliitto.

Zelený, Jindřich. 1980 [1968]. Logic of Marx. Lyhentänyt ja tšekin kielestä kääntänyt Terrell Carver. Oxford: Basil Blackwell. 